\title{
Acid-neutralizing capacity of Finnish mineral soils
}

\author{
HELINÄ HARTIKAINEN \\ Department of Agricultural Chemistry, University of Helsinki, \\ SF-00710 HELSINKI, Finland
}

\begin{abstract}
The acid-neutralizing capacity (ANC) was determined graphically from curves obtained in $\mathrm{HCl}$ titration (at a constant ionic strength $\mathrm{I}=0.1$ ) and was expressed as a quantity of acid $\left(\mathrm{meq} \mathrm{kg}^{-1}\right)$ needed to reduce the soil $\mathrm{pH}$ to 3.8. The relationship between $\mathrm{ANC}_{3.8}$ and soil characteristics was studied statistically.

In 84 soil samples, $\mathrm{ANC}_{3.8}$ ranged from 12 to $184 \mathrm{meq} \mathrm{kg}^{-1}$. The average $\mathrm{ANC}_{3.8}$ was highest in the heavy clay soils and lowest in the non-clay soils, but the differences between the various textural soil groups were not significant. In all soil groups the initial $\mathrm{pH}_{\mathrm{CaCl}_{2}}$ was relatively the most important factor explaining the variation in $\mathrm{ANC}_{3.8}$. Organic $\mathrm{C}$ was also a significant variable; this was considered to indicate the importance of cation exchange reactions of organic matter in acid-buffering. With the exception of heavy clay soils, oxalate-soluble $\mathrm{Al}$ significantly explained the variation in $\mathrm{ANC}_{3.8}$, suggesting that dissolution of $\mathrm{Al}$ hydroxides acted as a sink for $\mathrm{H}^{+}$ions and contributed to the neutralizing capacity at the reference $\mathrm{pH}$ of 3.8 .
\end{abstract}

Index words: acid-neutralizing capacity, soil acidity, titration, pH-buffering

\section{Introduction}

From the agricultural and ecological point of view soil $\mathrm{pH}$ is a very enlightening attribute of a soil. In addition to intensity of acidity it indicates the chemical and biological condition of a soil. Addition of $\mathrm{H}^{+}$ions to the edaphic system generally, but not always, decreases soil $\mathrm{pH}$; any alterations depend on the buffering properties of the respective soil. Soil acidification is actually defined as a decrease in acid-neutralizing capacity rather than as a decrease in pH (VAN BreEmen et al. 1983).
The intensity of buffering depends on the type of buffer system present, whereas the capacity is determined by its size. In a study of HartiKaINEN (1985) on the intensity of acid- and base-buffering, the acid quantities needed to reduce soil $\mathrm{pH}$ by 0.5 units were the higher the lower the initial soil $\mathrm{pH}$ was. It was further observed that in soils of different initial $\mathrm{pH}$ levels the variation in buffer values was explained by different soil factors. In the present study on the acid-neutralizing capacity and related soil characteristics, attention was paid to the capacity of soils in various 
textural classes to counterbalance the effect of acidifying factors.

\section{Materials and methods}

\section{a) Soil samples}

The experimental material, collected from southern and central Finland, consisted of 15 heavy clay soils $(60 \%$ or more clay fraction $<2 \mu \mathrm{m}), 41$ coarser clay soils (30-59 \% clay), 20 silt soils (main fraction $2-20 \mu \mathrm{m}$ ) and 8 fine sand soils (main fraction 20-200 $\mu \mathrm{m})$. The characteristics of the soils are presented in Table 1.

The air-dried 2-mm sieved samples were analysed for $\mathrm{pH}$ in a $1: 2,50.01 \mathrm{M} \mathrm{CaCl}_{2}$ suspension and for organic $\mathrm{C}$ by the wet combustion method (Graham 1948). Exchangeable basic cations displaced with $1 \mathrm{M} \mathrm{NH}_{4} \mathrm{OAc}$ (pH 7.0) were determined by AAS (Ca and $\mathrm{Mg}$ ) or by flame photometry (K and $\mathrm{Na}) . \mathrm{Al}$, $\mathrm{Fe}$, and $\mathrm{Mn}$ extracted with $0.05 \mathrm{M} \mathrm{NH}_{4^{-}}$ oxalate (pH 3.3) $(1: 20 \mathrm{w} / \mathrm{v})$ and $\mathrm{Al}$ extracted with $1 \mathrm{M} \mathrm{NH} \mathrm{N}_{4} \mathrm{OAc}$ (pH 4.8) (according to MCLEAN 1965) were determined by AAS.

\section{b) Determination of acid-neutralizing capacity}

Analogously to aqueous systems, the acidneutralizing capacity (ANC) of the soils can be determined by titration with a strong acid to a given reference $\mathrm{pH}$. In the present study, a batch titration method was used: $5 \mathrm{~g}$ of soil was treated with $50-\mathrm{ml}$ volumes of solutions containing $0,0.3,0.6,0.9,1.2$ or $1.5 \mathrm{meq} \mathrm{HCl}$ at an ionic strength of $\mathrm{I}=0.1$ (adjusted by $\mathrm{KCl})$.

After a 4-day equilibration (stirred once), the $\mathrm{pH}$ of the suspensions was measured with an analogous pH-meter, using a separate reference electrode. The titration graphs were drawn by expressing the measured $\mathrm{pH}$ as a function of acid added. The ANC was determined graphically from the curve and expressed as a quantity of acid (meq $\mathrm{kg}^{-1}$ ) needed to reduce the soil $\mathrm{pH}$ to 3.8 . In other words, the ANC stands for $\mathrm{H}^{+}$consumption between the $\mathrm{pH}$ of zero point of titration (ZPT), i.e. $\mathrm{pH}$ in $0.1 \mathrm{M} \mathrm{KCl}$, and $\mathrm{pH}_{\mathrm{KCl}} 3.8$. The subindex of ANC denotes the reference $\mathrm{pH}$.

The titration was carried out in duplicate. The precision of the method is described in details elsewhere (HARTIKAINEN 1985).

\section{Results and discussion}

The magnitude of ANC depends on the reference $\mathrm{pH}$ chosen. According to $\mathrm{V}_{\mathrm{AN}}$ BREEMEN et al. (1983), a pH of 5 might be appropriate for agricultural soils and that of 3 more reasonable for forest soils. The reference $\mathrm{pH}$ of 3.8 used in the present study is intermediate, but from an ecological point of view it may be universal for soils of undefined utilization.

The $\mathrm{ANC}_{3.8}$ ranged from 12 to $184 \mathrm{meq}$ $\mathrm{kg}^{-1}$, the average and median being 68.8 and $58.0 \mathrm{meq} \mathrm{kg}^{-1}$, respectively. It decreased with increasing initial soil acidity; the correlation of $\mathrm{ANC}_{3.8}$ vs. soil $\mathrm{pH}_{\mathrm{CaCl}_{2}}$ was $\mathrm{r}=$ $0.77^{* * *}(\mathrm{n}=84)$. The correlation between log

Table 1. Characteristics of soil samples. Means with confidence limits at 95 per cent, $\mathbf{w}=$ range.

\begin{tabular}{|c|c|c|c|c|c|c|}
\hline \multirow[b]{2}{*}{$\begin{array}{l}\text { Heavy } \\
\text { clays }\end{array}$} & \multirow{2}{*}{$\begin{array}{c}\mathrm{pH}\left(\mathrm{CaCl}_{2}\right) \\
5.1 \pm 0.3 \\
4.2-6.0\end{array}$} & \multirow{2}{*}{$\begin{array}{c}\text { Org. C } \\
\% \text { of D.M. } \\
5.0 \pm 1.3 \\
1.0-9.0\end{array}$} & \multicolumn{2}{|c|}{$\begin{array}{l}\text { Oxal. extr. } \\
\mathrm{Al} \\
\mathrm{mmol} \mathrm{kg}\end{array}$} & \multirow{2}{*}{$\begin{array}{c}\text { Acet. extr. } \\
\text { Al mmol kg-1 } \\
10.5 \pm 5.8 \\
2.2-39.4\end{array}$} & \multirow{2}{*}{$\begin{array}{c}\begin{array}{c}\text { Basic } \\
\text { cations } \\
\text { meq kg-1 }\end{array} \\
229 \pm 68 \\
103-613\end{array}$} \\
\hline & & & $\begin{array}{l}97 \pm 28 \\
45-255\end{array}$ & $\begin{array}{l}91 \pm 15 \\
30-149\end{array}$ & & \\
\hline $\begin{array}{l}\text { Coarser } \\
\text { clays w }\end{array}$ & $\begin{array}{l}5.2 \pm 0.2 \\
4.3-6.5\end{array}$ & $\begin{array}{l}4.2 \pm 0.6 \\
0.5-11.9\end{array}$ & $\begin{array}{l}62 \pm 6 \\
28-111\end{array}$ & $\begin{array}{l}72 \pm 9 \\
31-171\end{array}$ & $\begin{array}{l}6.4 \pm 1.4 \\
1.3-18.9\end{array}$ & $\begin{array}{c}128 \pm 13 \\
61-219\end{array}$ \\
\hline $\begin{array}{l}\text { Non-clay } \\
\text { soils w }\end{array}$ & $\begin{array}{l}5.2 \pm 0.3 \\
3.8-6.4\end{array}$ & $\begin{array}{l}3.5 \pm 0.7 \\
0.7-7.7\end{array}$ & $\begin{array}{l}60 \pm 12 \\
17-141\end{array}$ & $\begin{array}{l}62 \pm 6 \\
33-112\end{array}$ & $\begin{array}{l}7.1 \pm 2.3 \\
1.4-21.2\end{array}$ & $\begin{array}{l}98 \pm 17 \\
24-206\end{array}$ \\
\hline
\end{tabular}


Table 2. $\mathrm{ANC}_{3.8}\left(\mathrm{meq} \mathrm{kg}^{-1}\right)$ of soils in different textural groups. Means with confidence limits at 95 per cent level.

\begin{tabular}{llc}
\hline & \multicolumn{1}{c}{$\mathrm{ANC}_{3.8}$} & Range \\
\hline Heavy clays & $76.1 \pm 17.9$ & $22-134$ \\
Coarser clays & $69.3 \pm 9.4$ & $40-158$ \\
Non-clay soils & $64.1 \pm 12.7$ & $12-184$ \\
\hline
\end{tabular}

$\mathrm{ANC}_{3.8}$ and $\mathrm{pH}$ was not significantly closer $\left(\mathrm{r}=0.78^{* * *}\right)$. Furthermore, the neutralizing capacity tended to increase with the increase in exchangeable basic cations, the correlation coefficient being $\mathrm{r}=0.46^{* * *}$. It should be pointed out that when a heavy clay sample exceptionally rich in $\mathrm{NH}_{4} \mathrm{OAc}$ soluble cations was excluded, the value of $\mathrm{r}$ rose to $0.64^{* * * *}$.

On the other hand, $\mathrm{ANC}_{3.8}$ did not correlate with the clay content of soils $(r=0.12)$. In fact, there were great variations in the neutralizing capacity within the textural groups, but the differences between the various soil classes were not noticeable (Table 2). Certainly, the average $\mathrm{ANC}_{3.8}$ was highest in the heavy clay soils and lowest in the non-clay soils.

When the dependence of $\mathrm{ANC}_{3.8}(y)$ on the soil characteristics was studied by the regression analysis, only soil $\mathrm{pH}_{\mathrm{CaCl}_{2}}$, the content of organic $\mathrm{C}(\%)$ and oxalate-extractable $\mathrm{Al}$ $\left(\mathrm{mmol} \mathrm{kg}{ }^{-1}\right)$ were statistically significant variables $(P=0.05)$. In various textural soil groups the relationship conformed to the following equations:

Heavy clay soils:

$y=65.68 \mathrm{pH}+10.29$ org. $\mathrm{C}-307.59$

$\mathrm{R}^{2}=0.82^{* * *}$

Standard error of estimate $\mathrm{S}=14.66$

Coarser clay soils:

$y=55.91 \mathrm{pH}+2.12 \mathrm{org} . \mathrm{C}+0.45 \mathrm{oxal} . \mathrm{Al}-$ 257.81

$\mathrm{R}^{2}=0.88^{* * *}$

$\mathrm{S}=10.61$

Non-clay soils:

$y=51.91 \mathrm{pH}+7.95 \mathrm{org} . \mathrm{C}+0.26 \mathrm{oxal} . \mathrm{Al}-$ 246.97

$\mathrm{R}^{2}=0.81^{* * *}$

$\mathrm{S}=14.94$

On the basis of $\beta$-coefficients the initial soil $\mathrm{pH}$ was the most decisive factor in all soil groups. In the non-clay soils the relative importance of organic $\mathrm{C}$ content was greater than that of oxalate soluble $\mathrm{Al}$, whereas a reverse rank was found in the coarser clay soils.

More detailed studies are needed to clarify the causes for different buffer capacities of different soils and the mechanisms responsible for buffer action, but some interpretations can be discussed. Generally, in all textural groups the same factors explained the variation in the acid-neutralizing capacity. However, in the heavy clay soils, where the organic $\mathrm{C}$ and oxalate-soluble $\mathrm{Al}$ were highly correlated $\left(\mathrm{r}=0.77^{* * *}\right)$, the oxalate-soluble $\mathrm{Al}$ was excluded from the equation. Although it explained $17 \%$ of the variation it was insignificant owing to the small number of samples.

The relationship between ANC and pH is consequential, because a higher activity of $\mathrm{H}^{+}$ions (lower $\mathrm{pH}$ ) can be considered a result of a reduced inactivation ability of soil. The other factors explaining the variation in ANC depend on the reference $\mathrm{pH}$ chosen. Virtually, the reference $\mathrm{pH}$ determines which buffer systems are involved. UlRICH (1981) has demonstrated the characteristic chemical soil state for various buffer ranges and calculated the $\mathrm{pH}$ of 3.8 (in equilibrium soil solution) to represent the upper limit of the iron buffer range. In the present study, the oxalatesoluble $\mathrm{Fe}$ was insignificant in explaining the variation in $\mathrm{ANC}_{3.8}$, which suggests that the iron buffer range was not reached. The oxalate-soluble $\mathrm{Al}$, on the contrary, was a significant variable, infering that the dissolution of $\mathrm{Al}$ hydroxides might act as a sink for $\mathrm{H}^{+}$ ions. The buffering by this mechanism can be expected to be ample but ecologically harmful.

The contribution of organic $\mathrm{C}$ may be attributable to the significance of organic matter as cation exchanger and indicate the role of exchange reactions in acid-buffering. The $\mathrm{H}^{+}$ions exchange cations directly only on slightly acid (variable) charge sites (VEITH and SCHWERTMANN 1972) the main source of 
which in Finnish soils is generally organic matter. Thus, an influx of $\mathrm{H}^{+}$to soil implies a reduction in effective cation exchange capacity even though not necessarily in $\mathrm{pH}$. However, especially at higher reference $\mathrm{pHs}$, the organic $\mathrm{C}$ may be a poor measure of the buffering capacity due to organic matter. The $\mathrm{pK}_{\mathrm{a}}$ values of organic constituents range from 3.8 to 6.2 (MARTIN and ReEve 1958, HARGROVE and ThOMAs 1982), wherefore also the efficiency of organic matter as proton acceptor can be concluded to vary.

\section{References}

Hargrove, W.L. \& Thomas, G.W. 1982. Titration properties of Al-organic matter. Soil Sci. 134: 216-225.

Hartikainen, H. 1985. Acid- and base-titration behaviour of Finnish mineral soils. In preparation. (Manuscript available at Department of Agricultural Chemistry, University of Helsinki).

Graham, E.R. 1948. Determination of soil organic matter by means of a photoelectric colorimeter. Soil Sci. 65: $181-183$.

Martin, A.E. \& Reeve, R. 1958. Chemical studies of podzolic illuvial horizons. III Titration curves of

\section{SELOSTUS}

\section{Suomalaisten kivennäismaiden haponneutralointikapasiteetti}

\section{Helinä Hartikainen}

Helsingin yliopisto, maanviljelyskemian laitos, 00710 Helsinki

Laboratoriokoe tehtiin Etelä- ja Keski-Suomesta kerätyillă 84 maanăytteellă, joista 15 luokiteltiin aitosaveksi, 41 hiesu- tai hietasaveksi, 20 hiesuksi ja 8 hiedaksi. Ilmakuivista maista otettiin $5 \mathrm{~g}: \mathrm{n}$ eriä, joihin lisăttiin 50 ml titrausliuosta, jossa oli 0, 0.3, 0.6, 0.9, 1.2 tai 1.5 mekv $\mathrm{HCl}$ :ảă. Jokaisen titrausliuoksen ionivahvuus (I) oli săădetty $\mathrm{KCl}: 11 a ̉$ 0.1 :ksi. Neljän päivăn reaktioajan jălkeen suspensioiden $\mathrm{pH}$ mitattiin ja mittaustuloksista piirrettiin käyrä, jossa pH esitettiin happolisäyksen (mekv kg-1 maata) funktiona. Haponneutralointikapasiteetti (ANC) ratkaistiin graafisesti ja ilmoitettiin happomääränä (mekv $\mathrm{kg}^{-1}$ ), joka tarvittiin laskemaan maan $\mathrm{pH}$ 3.8:aan.
Further studies on the ANC values at various reference $\mathrm{pHs}$ are needed to give estimates on the susceptibility of our soils to various acidifying factors. On the other hand, also studies on the type and kinetics of proton consuming reactions are necessary in order to infer the ecological consequences of acidbuffering reactions.

Acknowledgement. The author wishes to thank the Maj and Tor Nessling Foundation for the grant which made it possible to complete this study.

organic-matter suspensions. J. Soil Sci. 9: 89-100.

McLean, E.O. 1965. Aluminium. pp. 978-998 in Methods of soil analysis. Agronomy 9 (2).

Van Breemen, N., Mulder, J. \& Driscoll, C.T. 1983. Acidification and alkalinization of soils. Plant and Soil 75: 283-308.

Veith, J. \& Schwertmann, U. 1972. Reaktionen von CaMontmorillonit und $\mathrm{Ca}-\mathrm{Vermiculit}$ mit Kohlensäure. Z. Pflanzenern. u. Bodenkde 131: 21-37.

Ms received September 6, 1985
Tutkituissa näytteissä $\mathrm{ANC}_{3.8}$ vaihteli $12-184$ mekv $\mathrm{kg}^{-1}$. Keskimääräinen neutralointikapasiteetti oli suurin (76 mekv kg-1) aitosavissa, seuraavaksi suurin (69 mekv $\mathrm{kg}^{-1}$ ) hiesu- ja hietasavissa ja pienin (64 mekv $\mathrm{kg}^{-1}$ ) hiesu- ja hietamaiden muodostamassa ryhmåssă. Maalajiryhmien văliset erot eivăt kuitenkaan olleet tilastollisesti merkitseviä. Koko aineistossa neutralointikapasiteetti ei korreloinut saveksen pitoisuuden kanssa. Saves- $\%$ ei myőskảän ollut tilastollisesti merkittăvă selittảjä regressioyhtälöissă, joilla pyrittiin kuvaamaan $\mathrm{ANC}_{3.8}: \mathrm{n}$ ja maan ominaisuuksien välistä suhdetta. Voimakkaimmin $\mathrm{ANC}_{3.8}$ riippui maan alkuperăisestă $\mathrm{pH}$ :sta. Orgaanisen 
hiilen pitoisuus oli merkittåvă selittajjä kaikissa maalajiryhmissä, minkả katsottiin olevan osoitus orgaanisen aineksen kationinvaihtoreaktioiden merkityksestă hapon puskuroinnissa. Aitosavien ryhmảă lukuunottamatta oksalaattiuuttoinen $\mathrm{Al}$ oli kolmas merkitsevăsti $\mathrm{ANC}_{3.8}: \mathrm{n}$ vaihtelua selittåvă tekijä. Tämä viittaa siihen, että $\mathrm{Al}$ hydroksidien liukenemiseen perustuva puskurointimekanismi alkaa tuntuvasti vaikuttaa neutralointikapasiteetin arvoon, kun referenssi-pH:ksi on valittu 3.8. 